\title{
THE ANALYSIS OF THE LANDSLIDE VULNERABILITY SUB WATERSHEDS ARUS IN BANYUMAS REGENCY
}

\author{
SUWARNO ${ }^{1 *}$, SUTOMO $^{1}$, Maulana Rizki ADITAMA ${ }^{2}$
}

DOI: 10.21163/GT_2019.142.10

\begin{abstract}
:
Landslide vulnerability is affected by several factors including the condition of the geology, geomorphology, soils, and land use. The purpose of this research is to examine landslide Vulnerability class by using synthetic geomorphological approach in the research area. Survey research method was use which includes field work and laboratory work. Field work intended for the mapping landslide of area, measurement and observation of the land characteristics. Laboratory work is aimed at analyzing the soil texture. The data of the field work and the laboratory are used to determine the landslide vulnerability class by using geographical information system technology. Landslide vulnerability class is analyzed by using 11 parameters. Data processing parameters of each land forms is done by giving values between the prone and not cartilage. The determination of the class prone determined how many parameters of value-prone. The results of the study show that the landslide vulnerability class research area is divided into two classes, namely medium and high vulnerability class. High vulnerability is dominating class with broad reaching $89.58 \%$ of the total area. A class of high vulnerability dominates due to various reasons including geological conditions i.e. all areas with sloping rocks of structure bedded with a slope of more than $10^{\circ}$, and arranged Halang and Tapak rock formations.
\end{abstract}

Key-words: Vulnerability, Landslides, Geomorphological approach.

\section{INTRODUCTION}

Disaster-prone is a condition or characteristics of the geological, hydrological, biological, climatological, geographical, social, cultural, political, economic, and technology in an area for a specific period which reduces the ability to prevent, attenuate, reaching preparedness, and reduced ability to respond to the impact of bad certain danger (law No.24/2007 RI about disaster management Chapter 1). The area of the landslide-prone is the protected area or the area of cultivation covering potential avalanche zones (PMPU No. 22/PRT/M/2007 on guidelines for Spatial Areas prone to Landslide). Landslide-prone areas can be interpreted as an area that is easy to landslide. The abundance of landslide and the density of incident occurrence is affected by several factors, they are the shape of the land surface morphology, geological conditions, the distance between the river flows, earthquakes (Havenith, et al., 2015).

\footnotetext{
${ }^{1}$ Geography Education Department of Universitas Muhammadiyah Purwokerto, Jl. Raya Dukuh Waluh Kembaran, Purwokerto, Jawa Tengah, Indonesia, *Corresponding author suwarnohadimulyono@gmail.com; sutomo@ump.ac.id ${ }^{2}$ Universitas Jenderal Soedirman, Indonesia, maulana.rizki.a@mail.ugm.ac.id
} 
The area characteristics that are used to determine the landslide vulnerability consist of slope, topography, vegetation cover, the framer of rocks, rainfall and the incidence of landslide. The effect of topographic factors on the landslide morphology is a form of vulnerability and a big slope, landslide will happen on a large hill with a slope morphology $10-15^{\circ}$ (Edoardo, et al., 2014). The geological structure area of faulting and tilting of rocks bedded composed of sedimentary rocks which have already experienced the weathering and vegetation cover change occurs, then the region will be much going of landslide (Kevin, et al., 2017; Luigi, et al., 2014). Rainfall is a factor triggering landslide events, landslide events more occur in regions with annual rainfall in wet years (Susana, et al., 2014).

Sub Watersheds Arus include into landslide vulnerability area. Landslide area is influenced by the physical condition of the land and due to human activities. When the management of land is not suitable, then it will trigger landslide. Landslides are very detrimental to the surrounding community because it may cause casualties, either loss of life or property. The things that need to be avoided in landslide management are related to human activities include cutting slopes for construction of roads, houses, farms and mining the rock and sand (Sartohadi, 2008).

The landslide incidence caused by human activities such as the use of land for agriculture, housing, roads, homes, farms and mining the rock and sand (Sartohadi, 2008). Cardinali, et al. (2002) explained the factors that cause landslide are physical factor such as the local geology and morphology. Geological factors consist of the type of materials/rocks, fracturing of rock mass structure of the mayor, while other factors consists of morphology, elevation, slope angle, slope aspect, type of avalanches, land use, soil type and rainfall (Glenn, et al., 2006; Nadim, et al., 2006; Thapa and Esaki, 2007; LAN, et al., 2004). Forest land use is less susceptible to landslides, because on forest land use less damage than wooded slopes, then on the land use of the forest with the same topographic factor will be less landslide events (Elmar, et al., 2017).

Landslide is a down movement the slopes of rocks and/or soil slipping along the plane of the surface. Landslide is always associated with a disruption of the balance of the relationship that exists between pressure and strength in the material above the slopes. The relationship between the pressure and the power is determined by factors such as altitude and the steepness of the slope and density, strength of cohesion and the shift of the material (Smith, 1996). Huabin, et al. (2005) distinguishing factor is the cause of landslide into two categories namely intrinsic variables such as the geological conditions and the structure of the slopes, and extrinsic variables such as rainfall and human activities. Human activity influence on landslide such as the manufacture of the roads and the railway construction, mining, development of the town in mountainous areas (Sassa, et al., 2007).

\section{METHODOLOGY}

Analysis of landslide vulnerability classes using parameters for landslide-prone areas issued by the Department of Public Works namely PMPU No. 22 / PRT / M / 2007. In the PMPU, the criteria of landslide-prone land classification are based on climatology, geomorphology, geology, soil and land use factors. These factors consist of 11 variables: 1) thick rainfall, 2) landslide events, 3) slope, 4) relief, 5) thick weathering, 6) texture, 7) permeability, 8) rock type, 9) layer structure rocks, 10) earthquakes, and 11) land use. The causal variable is considered to be vulnerable or not vulnerable based on Table 1 below. 
Table 1.

The Criteria of vulnerability causes to Determine the Landslide Vulnerability

\begin{tabular}{|c|c|c|c|c|c|}
\hline \multirow{2}{*}{ No } & \multirow{2}{*}{ Causes } & \multirow{2}{*}{ Variable } & \multirow{2}{*}{ Vulnerable Landslide } & \multicolumn{2}{|c|}{ Value } \\
\hline & & & & Yes & No \\
\hline 1 & Rain fall & Yearly rain fall (mm) & $\geq 2,500 \mathrm{~mm} /$ year & 1 & 0 \\
\hline 2 & $\begin{array}{l}\text { Landslide } \\
\text { Occurrence }\end{array}$ & Frequency & Landslide occurrence & 1 & 0 \\
\hline \multirow[t]{2}{*}{3} & \multirow[t]{2}{*}{ Topography } & Slope & $\geq 15 \%$ & 1 & 0 \\
\hline & & Relief & Hilly to mountainous & 1 & 0 \\
\hline \multirow[t]{3}{*}{4} & \multirow[t]{3}{*}{ Soil } & $\begin{array}{l}\text { Thickness } \\
\text { weathering }\end{array}$ & $\geq 90 \mathrm{~cm}$ & 1 & 0 \\
\hline & & Texture & Clay and its variant & 1 & 0 \\
\hline & & Permeability & Medium to slow & 1 & 0 \\
\hline \multirow[t]{3}{*}{5} & \multirow[t]{3}{*}{ Geology } & Rock & $\begin{array}{l}\text { Sedimentary rock: clay, marl, } \\
\text { tuff, limestone, sand at tertiary- } \\
\text { age, and pyroclastic }\end{array}$ & 1 & 0 \\
\hline & & Structure & $\begin{array}{l}\text { Layer of rock parallel with the } \\
\text { slope }\end{array}$ & 1 & 0 \\
\hline & & Earthquake & Earthquake influence & 1 & 0 \\
\hline 6 & Land Use & Type of land use & $\begin{array}{l}\text { Settlement, one-seasoned } \\
\text { farming with terrace, and fish } \\
\text { ponds }\end{array}$ & 1 & 0 \\
\hline
\end{tabular}

Source: Suwarno, et al., 2013.

Based on the assessment in Table 1, each variable is given a value that is vulnerable and not vulnerable. The parameters used for the assessment of landslide vulnerability classes are 11 variables that cause vulnerability. Eleven of these variables are categorized into two, which are vulnerable and not vulnerable. Variables categorized as not vulnerable are given a value of 0 (zero), while the variables categorized as vulnerable are given a value of 1 (one), because it is considered that each of these variables has the same degree of influence on the causes of landslide vulnerability, then given the same weight. Based on the many values causing landslide vulnerability, the lowest 0 and the highest value were obtained. Landslide vulnerability class was divided into 4 classes, namely very low, low, medium and high classes. The class interval width is calculated using Formula 1, then the width of the class interval $(11-0): 4=2.77$ is rounded to 3 . The landslide vulnerability class division is presented in Table 2 below.

Table 2.

The width of vulnerability class and landslide occurrence

\begin{tabular}{|c|c|c|}
\hline No & The numbers of landslide causes & Vulnerability class \\
\hline 1 & $\leq 2$ & Very low \\
\hline 2 & $3-5$ & Low \\
\hline 3 & $6-8$ & Medium \\
\hline 4 & $9-11$ & High \\
\hline
\end{tabular}

\section{RESULTS AND DISCUSSIONS}

The results of each variables are based on Table $\mathbf{1}$ and classified to determine the landslide susceptibility class based on Table 2. Landslide vulnerability classes in the research area consist of two classes of vulnerability namely medium and high class. The research area did not have landforms that entered the very low and low vulnerability classes. Landslide susceptibility classes are currently available in three landform units, namely landform units of Slope II Structural Hills, Valley of Slope I Structural Hills, Slope 
III Structural Hills. High landslide susceptibility classes are scattered in 5 landform units, namely landform units of Slope Synchronous Hills III, IV Slope Settlements, Slope V Slope Hills, IV Slope Structural Hills, and Slope V Structural Hills. Landslide vulnerability class distribution is presented in Figure 1 below.

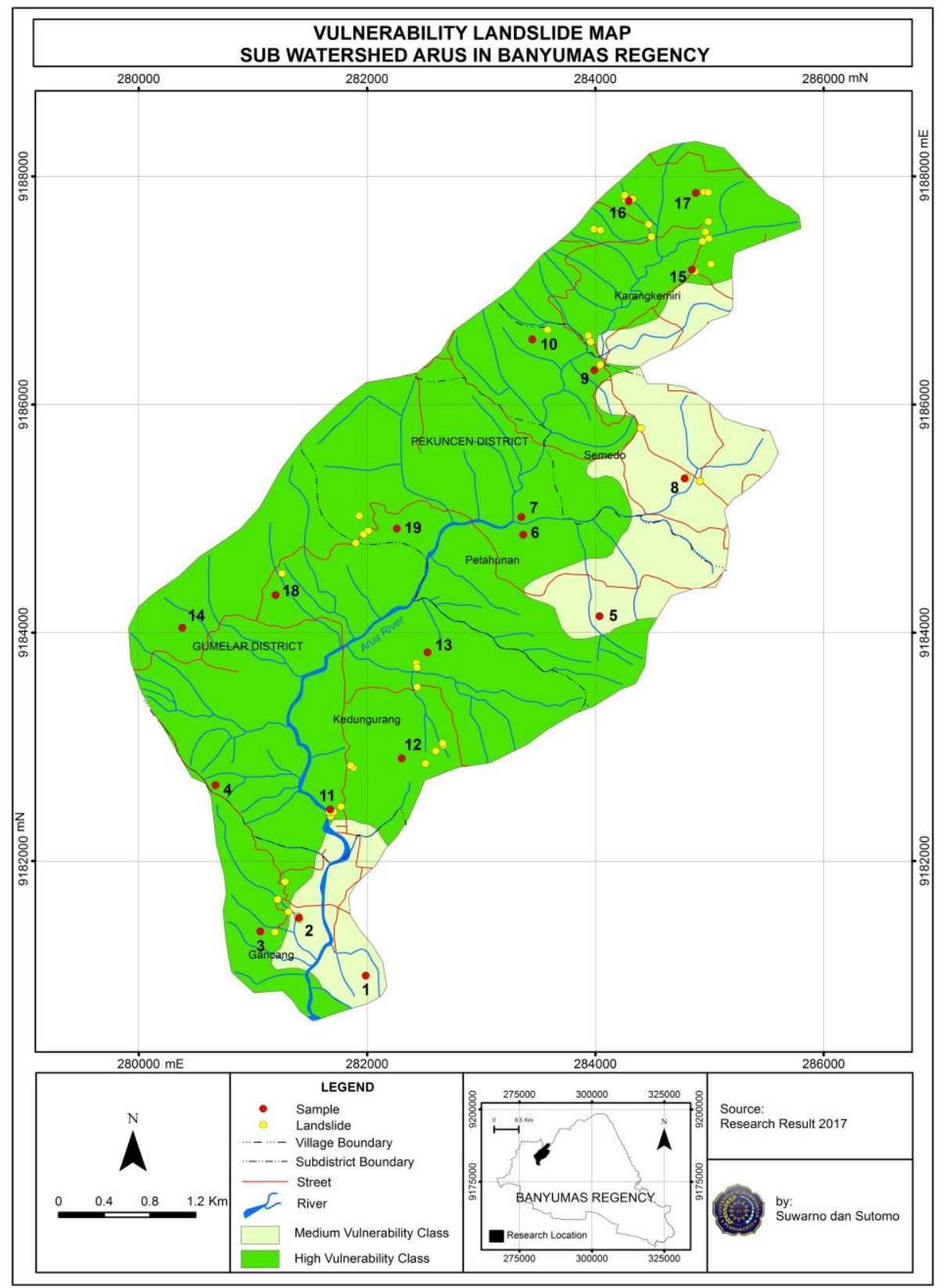

Fig.1. Landslide Vulnerability Map Sub Watersheds Arus in Banyumas Regency. 
Based on Figure 1 it can be seen that the distribution of landslide landscaping classes is being found in landform units with slope classes I to III. The high vulnerability class dominates due to various reasons including geological conditions, namely all regions with sloping rock layering structures with slopes of more than $10^{\circ}$, and composed of Halang and Tapak rock formations. These rock formations are composed of water-resistant rocks which are good slip fields for landslides. The area of each landslide class is presented in Table $\mathbf{3}$ below.

Table 3.

The width of each landslide vulnerability class

\begin{tabular}{|c|c|r|r|r|r|}
\hline \multirow{2}{*}{ No } & \multirow{2}{*}{ Vulnerability class } & \multicolumn{2}{|c|}{ Width } & \multicolumn{2}{c|}{ Landslide Occurrence } \\
\cline { 3 - 6 } & & (ha) & $(\%)$ & Sum & $(\%)$ \\
\hline 1 & Medium & 380.92 & 18,77 & 5 & 10.42 \\
\hline 2 & High & 1648.86 & 81,23 & 43 & 89.58 \\
\hline \multicolumn{2}{|c|}{ Sum } & 2029.78 & 100.00 & 48 & 100.00 \\
\hline
\end{tabular}

Source: Fig. 1

Based on Table 3 above, the study area of $819.23 \%$ entered a high vulnerability class, with a total landslide incidence of $89.58 \%$ of the total landslide events. The vulnerability class is currently occupying $18.77 \%$ of the total area, with landslide events $10.42 \%$ of the total incidence. The study area does not have very low and low landslide susceptibility classes, this can be caused by various factors. These factors include geomorphic conditions which are composed of structural landform units with various slope classes. Geological structure in the form of sloping and sloping layers. High annual rainfall of more than 2500 mm per year.

High vulnerability occupies the widest class III to V slopes. Landform unit that entered on the vulnerable high class is the sinklinal slopes of hills III, sinklinal hills, sinklinal hills IV slopes slope of V, structural slope hills IV, and structural slope Hills V. Landslide occurrence is found in the high vulnerability class. On a high vulnerability class with steep slopes, rock-lined sloping structure, morphology, the hills to the mountains, land use with the intensive management activities. Landslide in many research areas occur on the steep slopes of the suitable with the opinion of the (Chien-Yuan dan Wen-Lin, 2013; Mutasem,et al., 2013; Edoardo, et al., 2014; Ching-Ying, et al., 2015). Morphological factors that form the structural hills are also factors that led to the research area of the incoming high vulnerability class. According to (Reichenbach, et al., 2014) landslide distribution influenced by topography, morphology, hydrology, litologi, and land use.

The geological condition in the research area consist of structures sinkinal and bedded rocks are tilted, as well as Formation composed of Halang (Tmph), and the formation of Tapak (Tpt). Halang formation (Tmph) Tertiary age (Middle Miocene - end), composed of andesite, Tuff sandstones, marls and sandstones, breksi, sandstones. The formation of Tapak (Tpt) age of tertiary (Pliocene), consisting of rough colored greenish sandstones, marls, sandstones Temple looks greenish, the temple looks Tuff, and greenish marls (Suwarno and Sutomo, 2017). The geological condition of determining the high vulnerability class especially geologic structure and types of rocks. 
Sandstones and clays are one of the causes of the landslide high vulnerability class (Barančoková, et al., 2014). Age of rocks on the formation of Halang (Tmph) Tertiary age (Middle Miocene - end), at the age of these rocks occur landslide of 54.17\% (Suwarno and Sutomo, 2017). Landslide in Maierato most occur in the Miocene rocks from to PlioPleistocene ( Luigi, et al., 2014). Landslide in Central Europe a lot happens on the border between sedimentary rocks and volcanic rocks or (Piotr, et al., 2016).

Rainfall in the area of study is tall, an annual average of over $2000 \mathrm{~mm}$, on most of the average annual precipitation above $3000 \mathrm{~mm}$. Rainfall is the cause of high incidence of landslide. Rainfall is landslide trigger factors (Gao, et al., 2017), meaning that the incidence of landslide will quickly occur if supported by high rainfall.

\section{CONCLUSIONS}

Night-time Landslide vulnerability in research areas lies in the middle to high class. A high class vulnerability of its widest and covers in five units of land forms. A high class vulnerability is caused by various factors including high rainfall, condition of geomorphology, geology, and soil properties. Rainfall is spread evenly throughout the region. The research on area of geomorphology units is controlled by structural context, as the morphology of the area situated in the form of rolling hills and valleys with steep to rugged slope.

The geological conditions in the form of geological structure of synclinal folds and oblique layers, composed of sedimentary rocks of tertiary age. Solum is thick soil, soil texture dominated by clay and loam. The earthquake did not affect the vulnerability caused due to the research locations were not positioned near to the centers of earthquakes.

\section{ACKNOWLEDGEMENT}

The award, speech and high appreciation we coveyed to the Director of the DRPM KEMENRISTEKDIKTI, for giving us the trust and provided funding to conduct research on Skim Penelitian Strategi Nasional Intitusi.

\section{R E F E R E N C E S}

Barančoková M., Kenderessy P. (2014) Assessment of landslide risk using GIS and statistical methods in Kysuce region. Ekológia (Bratislava), 33 (1) 26-35.

Cardinali, M., Reichenbach, P., Guzzetti, F., Ardizzone, F., Antonini, G., Galli, M., Cacciano, M., Castellani, M., and Salvati, P. (2002) A geomorphological Approach to The Estimation of Landslide Hazards and Risks in Umbria, Central Italy, Natural Hazards and Earth System Sciences; 2, $57-72$.

Chien-Yuan Chen \&Wen-Lin Huang (2013) Land use change and landslide characteristics analysis for community-based disaster mitigation, Environ Monit Assess, 185, 4125-4139

Ching-Ying Tsou, Masahiro Chigira, Daisuke Higaki, Go Sato, Hiroshi Yagi, Hiroshi P. Sato, Akihiko Wakai, Vishnu Dangol, Shanmukhesh C. Amatya, Akiyo Yatagai, 2015. Topographic and geologic controls on landslides induced by the 2015 Gorkha earthquake and its aftershocks: an example from the Trishuli Valley, central Nepal, Landslides juornal.

DOI: $10.1007 /$ s10346-017-0913-9 
Edoardo Borgomeo, Katy V. Hebditch, Alexander C. Whittaker, Lidia Lonergan (2014) Characterising the spatial distribution, frequency and geomorphic controls on landslide occurrence, Molise, Italy, Geomorphology, 226, 148-161

Gao L., Zhang L.M., Cheung R.W.M. (2017) Relationships between natural terrain landslide magnitudes and triggering rainfall based on a large landslide inventory in Hong Kong, Landslides journal, DOI 10.1007/s10346-017-0904-x

Glenn,F.N., David, R.S., John, C.D., Glenn, D.T., and Stephen, J.D. (2006) Analysis of LiDARderived Topographic Information for Characterizing Landslide Morphology and Activity, Geomorphology, 73, $131-148$.

Havenith, H.B., Torgoev, A., Schlögel, R., Braunc, A., Torgoev, I., Ischuk, A. , Shan, T. (2015) Geohazards Database: Landslide susceptibility analysis, Geomorphology, http:// dx.doi.org/10.1016/j.geomorph.2015.03.019

Huabin, W., Gangjun, L., Weiya, X., and Gonghui, W. (2005) GIS-based Landslide Hazard Asscesment: an overview, Progress in Physical Geography, 29 (4), 548-567.

Kevin Roback, Marin K. Clark, A. JoshuaWest, Dimitrios Zekko, Gen Li, Sean F. Gallen, Deepak Chamlagain, JonathanW. Godt (2017) The size, distribution, and mobility of landslides caused by the 2015 Mai 7-8 Gorkha earthquake, Nepal, Geomorphology journal homepage: www.elsevier.com/locate/geomorph

Lan, H.X., Zhou, C.H., Wang, L.J., Zang, H.Y., and Li, R.H. (2004) Landslide Hazard Spatial Analysis and Prediction Using GIS in The Xiaojiang Watershed, Yunnan, China, Engineering Geology, 76, $109-128$.

Luigi Borrelli, Loredana Antronico, Giovanni Gullà, Giovanni Marino Sorriso-Valvo, (2014) Geology, geomorphology and dynamics of the 15 February 2010 Maierato landslide (Calabria, Italy), Geomorphology, 208, 50-73.

Mutasem Sh. Alkhasawneh, Umi Kalthum Ngah, Lea Tien Tay, Nor Ashidi Mat Isa, and Mohammad Subhi Al-batah (2013) Determination of Important Topographic Factors for Landslide Mapping Analysis Using MLP Network, The ScientificWorld Journal Volume Article ID 415023, 12 pages, http://dx.doi.org/10.1155/2013/415023

Muhammad Mukhlisin, Ilyias Idris, Al Sharif Salazar, Khairul Nizam \& Mohd Raihan Taha (2010) GIS Based Landslide Hazard Mapping Prediction in Ulu Klang, Malaysia, ITB J. Sci., 42 A, (2), 163-178

Nadim,F., Rodolf, P., Herbert, E., Herbert, K., and Steven, K. (2006) An Introduced Methodology for Estimating Landslide Hazard for Seismic and Rainfall Induced Landslides in a Geographical Information System Environment, ECI Conference on Geohazards, Lillehammer, Norway.

Piotr Migoń, Kacper Jancewicz ,Milena Różycka, Filip Duszyński, Marek Kasprzak (2016) Largescale slope remodelling by landslides - Geomorphic diversity and geological controls, Kamienne Mts., Central Europe, Geomorphology, journal homepage: www.elsevier.com/locate/geomorph

Reichenbach, P., Busca, C., Mondini, A. C., Rossi, M. (2014) The Influence of Land Use Change on Landslide Susceptibility Zonation: The Briga Catchment Test Site (Messina, Italy), Environmental Management, 54, 1372-1384, DOI: 10.1007/s00267-014-0357-0

Peraturan Menteri Pekerjaan Umum Nomor 22/PRT/M/2007, tentang Pedoman Penataan Ruang Kawasan Rawan Bencana Longsor.

Sartohadi, J., 2008. The Landslide Distribution in Loano Sub-District, Purworejo District Central Java Province, Indonesia, Forum Geografi, 22 (2), 129-144.

Sassa, K., Fukuoka, H., Wang, F., dan Wang, G. (2007) Progress in Landslide Science, Springer Berlin Heidelberg, New York.

Schmaltz E.M., Steger S., Glade T. (2017) The influence of forest cover on landslide occurrence explored with spatio-temporal information, Geomorphology 290, 250-264

Smith, K. (1996) Environmental Hazards, London and New York. 
Susana Pereira, José Luís Zêzere, Ivânia Daniela Quaresma, Carlos Bateira, (2014) Landslide incidence in the North of Portugal: Analysis of a historical landslide database based on press releases and technical reports, Geomorphology, journal homepage: www.elsevier.com/locate/geomorph.

Suwarno (2018) An Analysis of Landslide Occurrence Distribution and Geomorphological Conditions of Arus River Sub-Watershed in Banyumas Regency, 5th International Conference on Community Development (AMCA 2018), Advances in Social Science, Education and Humanities Research, volume 231.

Suwarno and Sutomo (2017) Model Analog Potensi Bencana Alam Longsorlahan Dengan Pendekatan Geomorfologikal Di Sub Das Kali Arus Kabupaten Banyumas, Laporan Penelitian, LPPM Universitas Muhammadiyah Purwokerto

Thapa, B.P., and Esaki,T. (2007) GIS-based Quantitative Landslide Hazard Prediction Modelling in Natural Hillslope, Agra Khola Watershed, Central Nepal, Bulletin of the Department of Geology, Tribhuvan University, Kathmandu, Nepal, 10, 63 - 70.

Tareq H. Mezughi, Juhari Mat Akhir, Abdul Ghani Rafek and Ibrahim Abdullah (2010) Landslide Susceptibility Assessment using Frequency Ratio Model Applied to an Area along the E-W Highway (Gerik-Jeli), American Journal of Environmental Sciences. 7 (1), 43-50. 